\title{
Degradation and Protection of Wetlands in Special Nature Reserves in Vojvodina
}

\section{Stojanović, Vladimir ${ }^{1}$}

\begin{abstract}
In accordance with ecological, economic, scientific and cultural importance of wetlands and their ecosystems, in the last couple of years there has been a much greater interest in these areas and their adequate preservation. Moreover, that is because wetlands are considered to be areas affected by various phenomena. As conditions of natural-geographical environment became favourable, numerous floodable plains emerged in valleys of big rivers in Vojvodina, both in geological and the near past. Inundant zones in alluvial river plains, thanks to hydrological flood processes at times of high water levels, were extremely favourable for the development of heterogeneous plant and animal world. When man appeared on the historical stage of natural and authentic entities of Vojvodina, building settlements near big rivers by the rule, i.e. where life conditions were the most favourable - these kinds of areas gradually started disappearing. Now, great effort is invested in order to preserve them. The research was conducted in the following special nature reserves: "Gornje Podunavlje", "Karađorđevo", "Koviljskopetrovaradinski rit", "Obedska bara", "Stari Begej-Carska bara".
\end{abstract}

Key words: Degradation, Nature reserves, Protection, Serbia and Vojvodina

\section{Vladimir Stojanović}

Faculty of Natural Science, Department for Geography, Tourism and Hotel Management, Trg Dositeja Obradovića 3, 21000 Novi Sad, Serbia

\section{Introduction}

Wetlands, with their swamps, marshes and water surfaces on peat land, natural and artificial, steady and periodical, with stagnant or running water, are becoming an area of interest in the field of environmental protection. They have a key ecological function as regulators of water regime and as places of rich biodiversity. These areas often unite significant economic, cultural, scientific and recreational values of their territory and that is why they have to be preserved. Human ecological faltering and the loss of these kinds of ecosystems can cause a serious damage to the environment (The Convention on Wetlands - brochure, 200o).

It was not unusual for valleys of large rivers and their floodable plains to become centers of the earliest civilizations. Many wetlands played an important role in the development of human society. That is simply reflected through the importance of water in human life. Advanced techni- cal and technological accomplishments leave an impression that man is independent of nature. However, natural disasters, such as floods, storms, erosions, and droughts - suggest the opposite. The reality is that the civilization is still quite dependant on nature and the ecosystems in the surrounding area. The historical dependence of man and society in wetlands is noticeable on the example of special nature reserves in the valleys of the rivers in Vojvodina. A medieval town of Bodrog, which is also mentioned as the centre of the whole region, was located on the territory of special nature reserve "Gornje Podunavlje". Its ruins date back to the beginning of $17^{\text {th }}$ century. An old fortress with a tower, next to the Danube and the Tis$\mathrm{za}$, can be seen on the old coat of arms of the region (Radovanović, 1997). The ruins of the medieval fortification Bač, once the historical centre of this part of the Pannonian plain, is placed north of the special nature reserve "Karađorđevo", in the me-

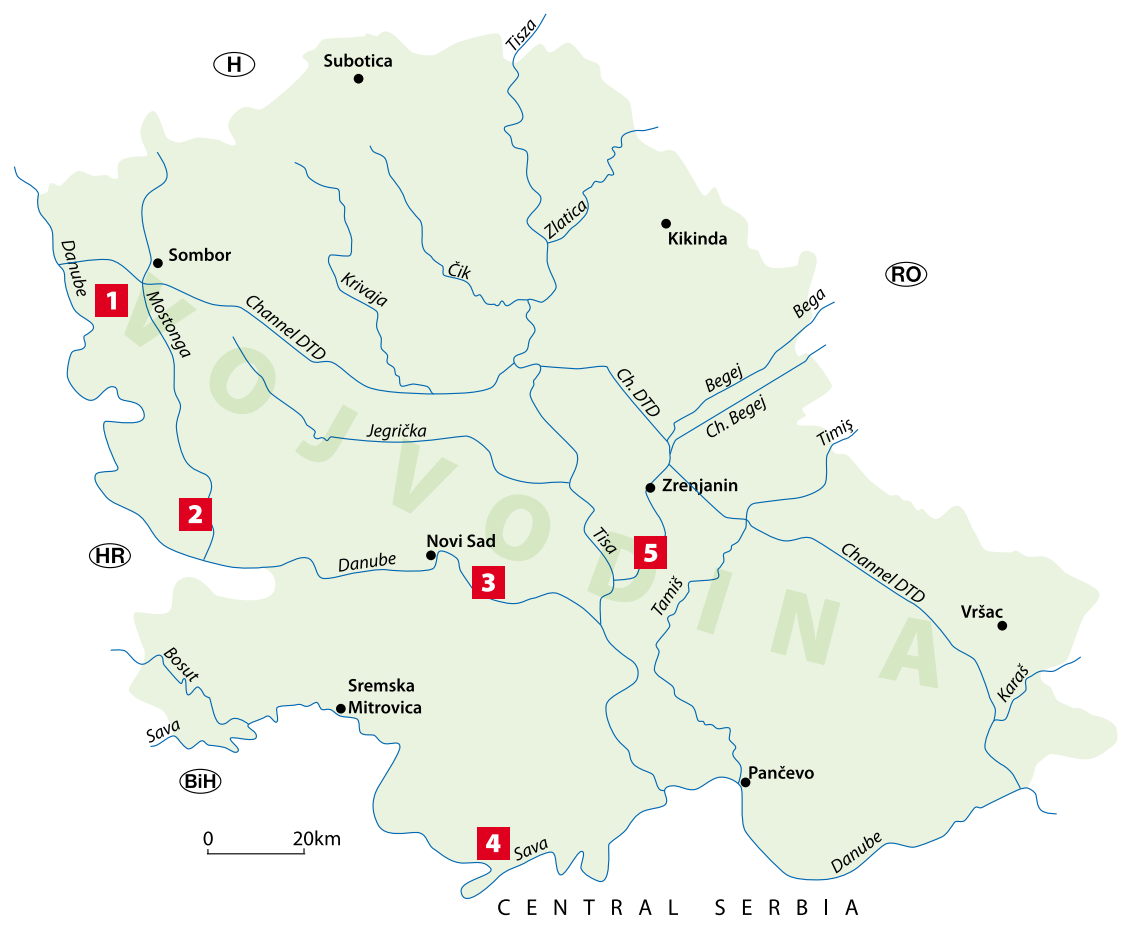

Figure 1 Geographical position of wetlands in floodable plains of rivers in Vojvodina; 1. SNR "Gornje Podunavlje, 2. SNR "Karađorđevo", 3. SNR "Koviljsko-petrovaradinski rit", 4. SNR "Obedska bara" and 5. SNR "Stari Begej - Carska bara" 
ander of the Mostonga river. Still, there are old walls of the Kupinik fortification on the rim of Obedska bara. It belonged to Hungarian and Serbian rulers and historically recognized as rather important. These historical components are just one of the criteria for the recognition of values and importance of wetlands.

Naturally, the times have changed and wetlands have gained a completely different function lately. Their strategic importance got lost, whereas economic importance is constantly rising, in accordance with their natural resources. The same situation is in Vojvodina as well. At one moment, especially before the protection of wetlands, natural values in floodable plains of big rivers in Vojvodina were seriously endangered. An abundance of wood material and other resources, and even a thought about potential cultivated fields on their territory - represented a danger for these unique natural complexes. The decision to protect wetlands, through the protection of special nature reserves, gives us hope that these areas, in the spirit of sustainable development, will be preserved for future generations (Stojanović, 2004). However, is everything that simple and without problems?

\section{Researched model}

Law on the environmental protection in Serbia identifies the following types of protected natural resources in Serbia: national park, park of nature, area of exceptional natural values, nature reserve (general), special nature reserve, natural rarities. Special nature reserve can be defined as "an area where one or more natural values is fully expressed and which needs to be specially protected, or natural phenomena that need to be closely observed or directed" ("Official Gazette of the Republic of Serbia”, No. 66/91).

Special nature reserves - "Gornje Podunavlje", "Karađorđevo", "Koviljskopetrovaradinski rit", "Obedska bara", "Stari Begej-Carska bara", are placed on the banks of big rivers in Vojvodina - the Danube, the Sava and the Begej. The importance of the ecosystems in those reserves is in direct relationship with rivers that created them, both in the present - through floods, and in the past, historically-geographically observed - through the evolution of their basic characteristics. Those are mainly "wet areas" or "wetlands", where marshes and swamps prevail. Two of the mentioned special reserves belong to Ramsar areas ("Obedska bara" and "Stari Begej-Carska bara”), and another two are recommended to also become Ramsar areas ("Gornje Podunavlje" and "Koviljskopetrovaradinski rit”).

Special nature reserves in Vojvodina, when observed for the very first time, con-

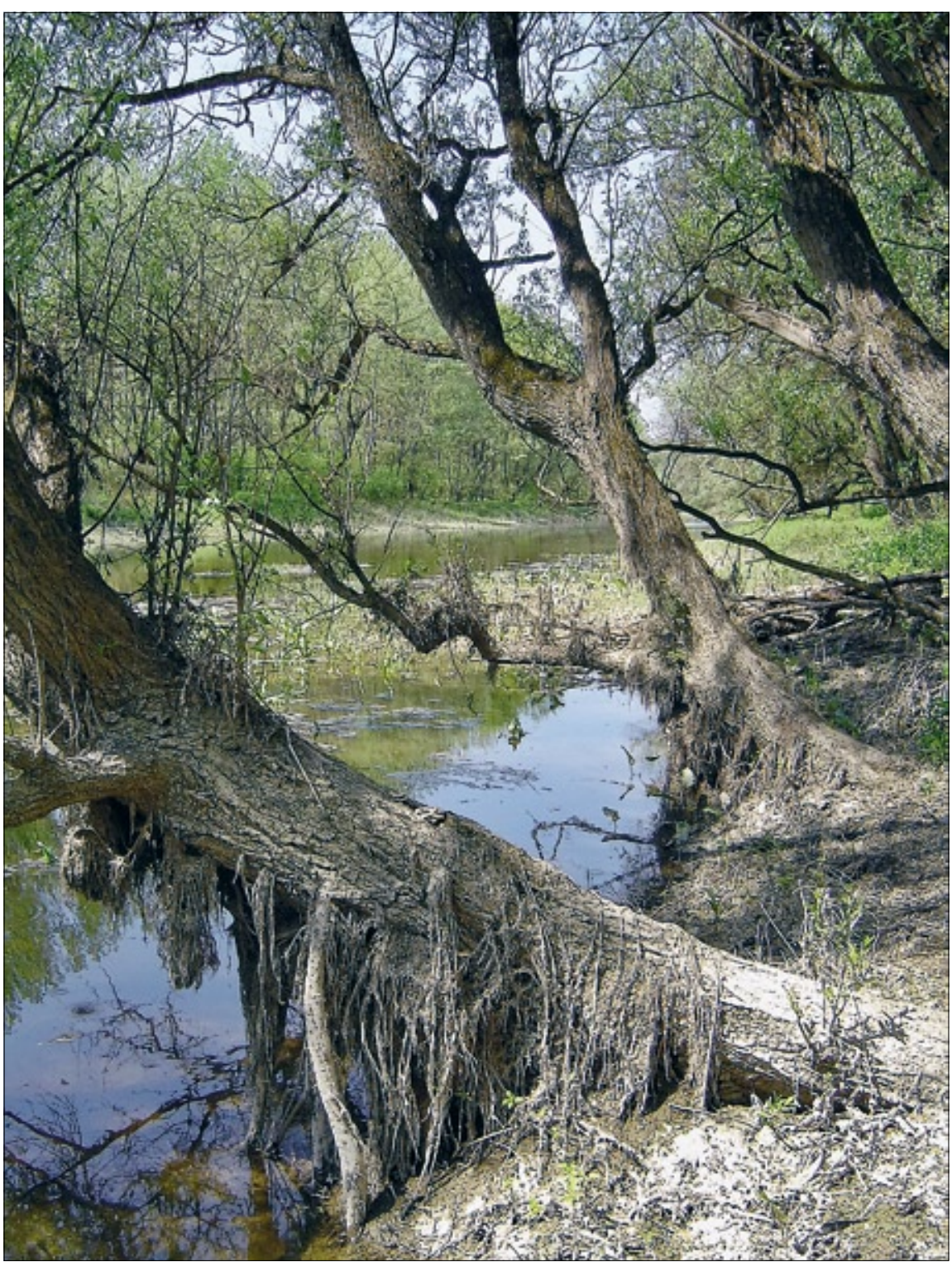

Figure 2 Special Nature Reserve "Gornje Podunavlje" - potential Ramsar area

firm a hypothesis on the importance of numerous components in these wet, swampy areas. The economic importance lies in the development of forestry, hunting, fishery and tourism, and some other activities as well, that can be a source of important income. The income could be also used to cover expenses of the environmental protection. Special nature reserves, i.e. areas that they cover, helped the population of surrounding places in cultural development, a thing that is noticeable even today in styles of their houses, settlements and customs. Special nature reserves in Vojvodina are the gathering point of many researches and scientists of different profiles and interests, a fact that irrefutably proves their scientific function. Excursion impor tance is performed by a large number of excursionists, fishers, and tourists as well, that seek alienation from modern, chaotic way of life in these kinds of natural entities. All these confirm the interest of different economic and social categories in the usage of special nature reserves, which actually only proves a thesis about their advantages. That is why it is necessary to harmonize all the needs and put them in the correlation with protective function. The solution of that task lies in the smart usage that today, at the beginning of $21^{\text {st }}$ century, is called sustainable usage. That kind of usage enables present generations to use resources, without causing any damage to future generations. Sustainable usage should also help man support natural prosperity in ecosystems.

\section{The importance of wetlands}

In valleys of big rivers, wetlands are considered important as controllers, i.e. factors of flood prevention. These natural regulators are cheaper than artificial systems of expensive protection and far cheaper than reclamation of flood consequences. Neglecting these facts, i.e. building of dikes along the rivers, forces many countries to restore ecosystems of wetlands. The fact remains that dikes represent an efficient way of flood protection. However, their building is sometimes uncompromisingly performed when surrounding 


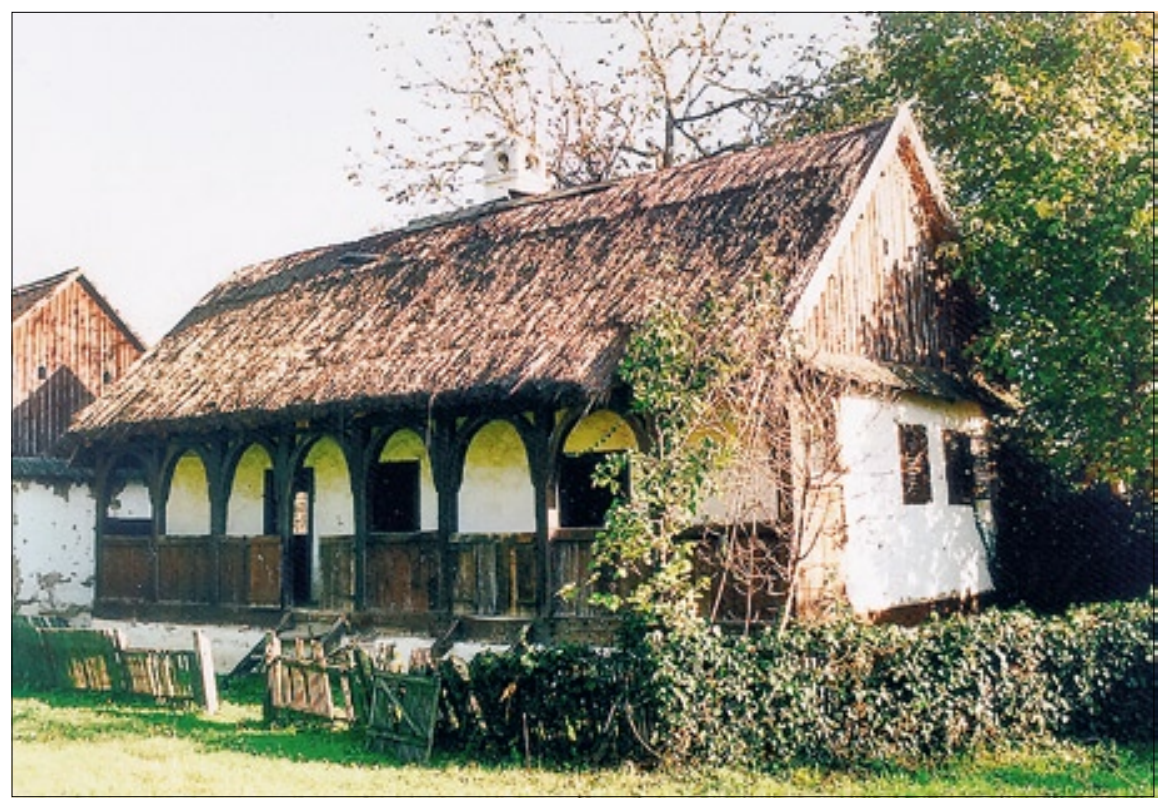

Figure 3 Traditional architecture on the rim of the Special Nature Reserve "Obedska bara" ecosystems are concerned. That condition now forces experts to begin with the recognition of these kinds of areas in our country too, and the best example is marsh "Monoštorski rit" in the special nature reserve "Gornje Podunavlje".

Wetlands are also areas of a very rich biodiversity. Disregarding the fact that these areas cover only $1 \%$ of the Earth surface, more than $40 \%$ of all living species and $12 \%$ of all animal species are concentrated in them (Wetland, values and functions, year unknown). These numbers deserve respect, and even greater importance is assigned to economic and financial evaluation of biodiversity. Special nature reserves as examples of wetlands in our country are also centres of heterogeneous biodiversity where rare and protected plant and animal species are to be found, many of which are on the National red list of endangered species.

Wetlands are natural reservoirs and storehouses of numerous natural products used for different purposes. Some of them are directly used for nutrition, while others, after being processed in the industry gain their final form. Here, we can mention rice and fish, as the most famous wetland products in the world that enable existence for millions of people around the planet. Moreover, there are fruit, seashells, animal meat, leather, wood building material, fire-wood, herbs, materials used for medicines, plants that give textile, alcohol, vinegar, cattle food, and other products. Interdependence of local people and wetlands is noticeable on the example of special nature reserves in Vojvodina. It was especially on a large scale in the past. Building material, that was used for the building of the whole settlements on the edges of these areas was also found there. Those are mainly wood and reed that were used for covering of roofs. Furthermore, there were also numerous food products, such as fish and venison. Nowadays, since they are classified as protected natural resources, special nature reserves are sources of building material, since forestry is one of the most common economic branches especially in "Gornje Podunavlje", "Koviljsko - petrovaradinski rit", "Obedska bara". Almost all are areas with high level of fish catch, the main source of income for significant number of people. In certain reserves there are beehives, i.e. apiculture is being developed thanks to phytodiversity. Finally, scenic and esthetic values can be considered as an additional "product", which contributes to the development of tourism.

Value and function of wetlands can be observed through a prism of cultural importance. For many nations and members of different cultural communities these wetlands represent important historical, religious and archeological places of priceless significance for their cultural development. In case of special nature reserves, their wetlands are of great importance for the cultural development of local communities that, in harmony with multinational characteristic of Vojvodina, belong to different nations (Serbs, Hungarians, Croats, Romanians, etc.). Ecosystems of wetlands had a great influence on their way of life, tradition, culture and customs.

Wetlands represent fragments of authentic nature in Vojvodina, which disappeared under the influence of man, who transformed them into cultivated land. The enable future generations to face important natural phenomena on the spot. Secondly, resources of special nature reserves and the rivers were used by the ancestors of the local population. The existence of a certain number of people and their households depends on these resources even today. The possibility to use them should be preservation of these ecosystems would also given to future generations, according to the principles of sustainable development - to the same or even greater extent. That is why efforts should be made to fit activities such as forestry, fishery, hunting, industrial production within the frames which would never endanger the natural scope of resources.

\section{Degradation of wetlands}

The influence of humans on special nature reserves is evident and fiercely alters ecosystems of these protected natural resources. The key influence upon these wetlands was observed during $19^{\text {th }}$ and $20^{\text {th }}$ century, with expressive meliorative works that spread over Vojvodina. Significant changes in the ecosystems of special nature reserves were achieved by dike building, draining of floodable plains, changes of river courses, and building of canal network. This is confirmed by comparison of archive and contemporary geographical maps. The crucial influences that gave physiognomy to today's nature of special nature reserve "Gornje Podunavlje" occured at the end of $19^{\text {th }}$ and the beginning of $2 \mathrm{O}^{\text {th }}$ century, when regulation works on the digging of the new Danube's riverbed were conducted. Three water canal were dug: Blaževački, between $1,386^{\text {th }}$ and $1,383^{\text {th }}$ river kilometre, Sigajski between $1,416^{\text {th }}$ and $1408^{\text {th }}$ river kilometre and Dravski between $1,386^{\text {th }}$ and $1,383^{\text {th }}$ river kilometre. Blaževački water canal cut off the meander around Blaževac, Sigajski water canal cut off meanders around Veliki and Mali Kazuk, Siga, Ampovo and Adica, whereas Dravski water canal cut off the meander that surrounds Srebrnica (Bukurov, 1975).

The Mostonga River in special nature reserve "Karađorđevo" also experienced severe changes. The beginnings of the human influence on the Mostonga date back to $15^{\text {th }}$ century when it was regulated that the ships from the Danube can undisturbingly sail to the fortress in Bač (Dudas, 1896). At the end of $18^{\text {th }}$ and the beginning of $19^{\text {th }}$ century, when Great Bačka Canal was dug, its riverbed was cut off. The route of the canal overlapped the riverbed of the Mostonga in the length of $2.5 \mathrm{~km}$. Since the water level in the canal was relatively high, draining of excessive water from Mostonga's marshes was made difficult. That forced the inhabitants of surrounding placed to finance the first works on the digging of this river's waterbed. Situation was similar in the south parts of the river course, where certain works were conducted during $19^{\text {th }}$ century. (Dedić, Božić, 1998). After the World War II the ideas on the further control of the river were realized. After the construction of the hydro-system Danube-Tisza-Danube, whose main principle was to include existing wa- 
tercourses into its network, the Mostonga experienced its key transformation. From Sombor to Bač, the Mostonga was canalized and included into the canal network. The overall length of the natural river course is $58.4 \mathrm{~km}$ (Milošev, 1998). All this resulted in the disappearance of the delta that the Mostonga built at its mouth into the Danube, which was also a very important wetland.

Similar to previous cases, one of the basic influences of man and his activities in the special nature reserve "Koviljsko petrovaradinski rit" is its influence on hydrological characteristics and water regime. Koviljsko - petrovaradinski rit is situated in the Danube's alluvial plain, that is flooded in the time of high water levels, when the river breaks through the system of natural depressions and canals all the way to the furthest parts of the marsh and then withdraws. Numerous human activities, together with natural processes, regularly fill depressions and thus prevent the water from breaking through. Those tendencies lead to even greater draining of Koviljsko - petrovaradinski rit, thus threatening to completely destroy this unique natural complex. Draining endangers the surface water aquifer in the north parts of Koviljski rit, especially stagnant tributary the Tonja. Due to these conditions, an initiative to clean the swamp was yielded. In Kozjak area ( $1^{\text {st }}$ level of protection), those works were already conducted and the course of the Danube was linked to its branch, thus enabling a normal flow of water into this part of the marsh. Petrovaradinski rit is under similar condition. Undisturbed navigability by boat to the Danube's branch near Sremski Karlovci depends on the water level. The north parts of the branch got solidified, thus cutting off the marshes and branches in the other part of the marsh. That is why similar actions are also necessary here.

In special nature reserve "Obedska bara", which belongs to a group of the oldest protected natural resources in the world, we can notice violation of basic hydrological characteristics and great water deficit. Reduction of open water surfaces as well as their weak flow is caused by greater human influence, that culminated during $2 \mathrm{O}^{\text {th }}$ century. Apart from human influence, decrease of water area in this wetland is also the result of natural processes. The size of aquifer, especially in Obedska bara, increased greatly. Today, this natural phenomenon is endangered more than ever before. Disturbance of water regime and water flow is conditioned primarily by filling of the supply canal Revenica and excessive deepening of the draining canal Vok.

Changes in the ecosystems of special nature reserve "Stari Begej-Carska bara"

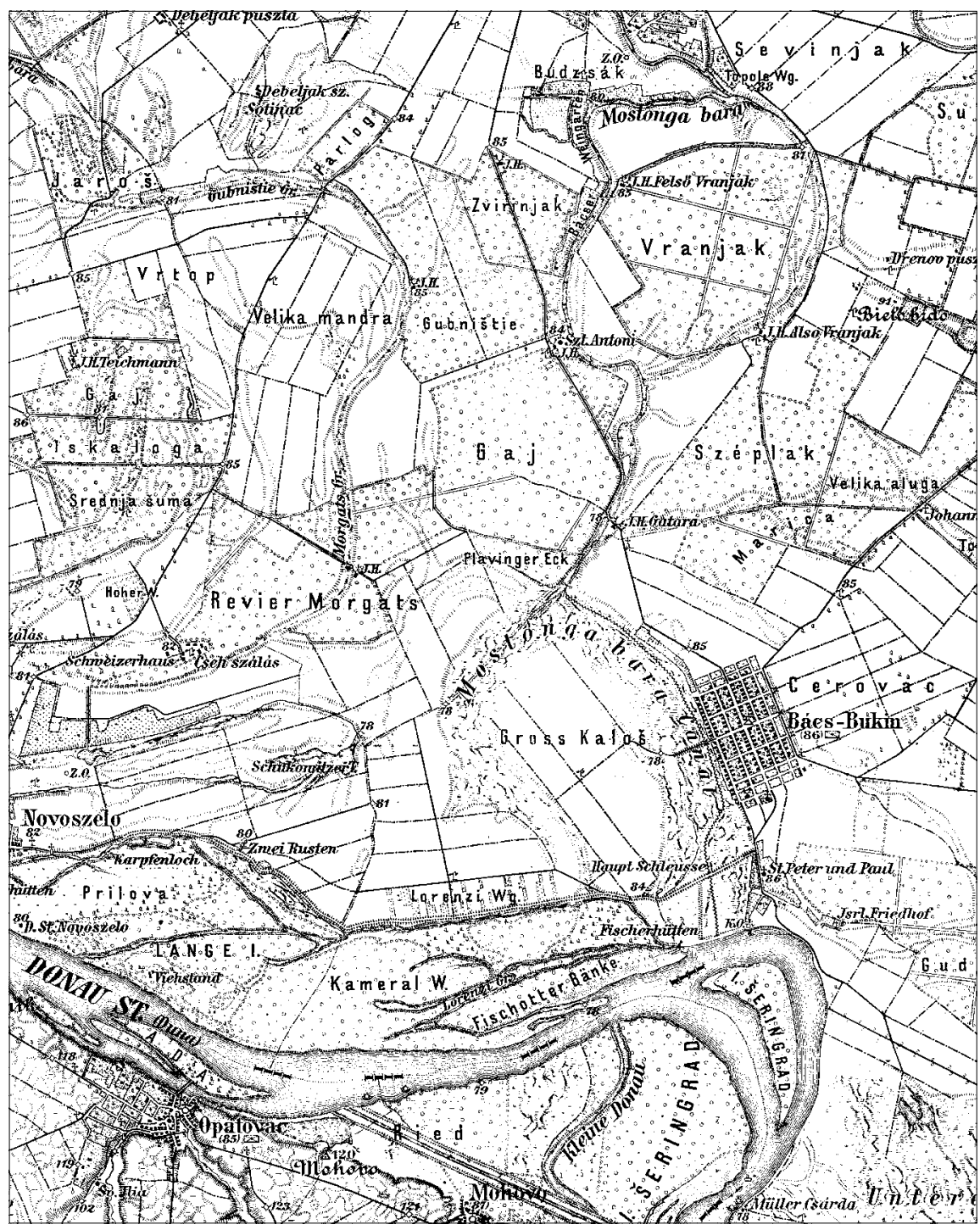

Figure 4 The Mostonga delta before vital regulations, at the beginning of $20^{\text {th }}$ century

occured as the result of digging of the new riverbed of the Begej; river that is very important for this protected natural resource. The works began in the mid 196os, as part of the construction of the hydro-system Danube-Tisza-Danube. The Begej canal (navigable Begej) was opened for river traffic in 1971, when the works on the damming of the former riverbed were finished, from near the building of the present hotel Sibila up to the lock on the mouth into the Tisza. That completely changed the water regime of the river. The damming of Tiganjica and Perleska marsh had an especially negative influence on the basic characteristics of this region, which consequently lead to the shoaling and decreasing of those depressions. In just a few years, whole complexes were covered in willows and marsh macrophytes. The Stari Begej was also dammed a bit more southwards, near Perlez, thus connecting old and new dike. Those changes in the surface hydrography of today's special nature reserve probably significantly reflected on ground waters, which influenced both hydrological and biogeographical characteristics of the whole region.
Dike building along rivers had the greatest negative influence on wetlands in Vojvodina, which is especially noticeable in "Gornje Podunavlje" and "Stari Begej-Carska bara". The area between Sig and Kazuk is situated in marsh Monoštorski rit, west from Bački Monoštor. The whole area is "protected" with dikes. As such that area between Sig and Kazuk stands for the symbol of changed ecosystems in special nature reserve "Gornje Podunavlje". Similar situation is observed in special nature reserve "Stari Begej-Carska bara", where dike building had a great influence on basic physiognomy of the scenery and on geographical characteristics. When a new route of the Begej River was dug (the Begej canal - navigable Begej), new dikes for protection from high waters were also built and they have a strong influence upon the area of today's special nature reserve, whose territory is completely surrounded by dikes. The last years when floods were recorded 1972 and 1973.

Some other ways of degradation are also noticeable. Destroying of authentic plant and animal world is the result of the nursery planting of Euro-American pop- 


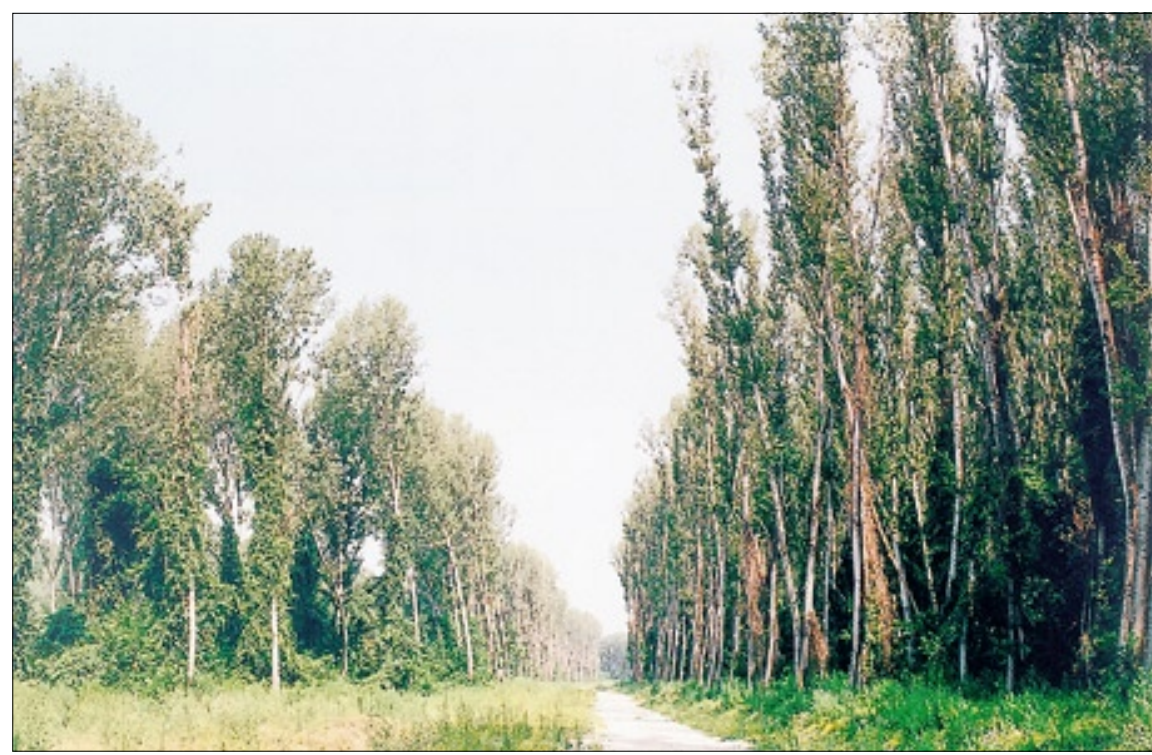

Figure 5 Euro-american poplars - danger to authentic ecosystems of wetlands

lars, that completely changes the appearance of the wetlands. Some of the reserves experience extremely negative intensive changes through application of protective measures, i.e. through poor management. However, the level of endangering these natural resources has not reached critical level, when they are considered lost. With an adequate protection program, many of endangered ecosystems could be restored and brought back to their original state.

\section{How to act in the future?}

Special nature reserves with their wetlands are protected according to the regulations proclaimed by the Government of the Republic of Serbia. Regulations issue all permitted and prohibited activities in these protected natural resources, as well as duties of the director of the protected natural resource. That is the legal frame within which promising future and qualitative evaluation of these natural entities is guaranteed. Management of these areas should provide the preservation of valuable ecosystems. Issues of repeated overflowing of inundant terrains are being examined and that is one step further towards the revitalization of degraded wetlands.

The resources of wetlands in special nature reserves still represent a strongpoint for certain economic activities that are believed to destroy their authentic characteristics. This particularly implies to forestry and the planting of poplars. According to CORINE classification, these wetlands do not have a character of a forest, but do have a character of agricultural areas. Plantations significantly change natural look of reserves and wetlands, which means that this operation should be completely avoided. The solution should be sought in different economic evaluations of biodiversity in wetlands. These areas do offer resources for economic activities that would not completely destroy them. Some of those activities are partially present, and traditionally known from previous centuries. Those are fishery, reed manufacturing and apiculture. Products of these activities are in great demand on the market because of their healthy and ecological components.

Local community should be also included in the process of the protection of special nature reserves, because it is an important factor of sustainable development. The concept of sustainable development must be and can be brought to a higher level through strengthening of consciousness about the necessity of nature protection and its rational exploitation. Local population are not well informed either about special nature reserves in whose hinterlands they live, or about their protection, permitted or prohibited activities inside the very reserve and areas with different regime of protection, or about wider possibilities of their exploitation. That is why the solution for that situation must be looked for in finding adequate mechanisms for better education of the population, development of the consciousness that they belong to a certain protected natural resource. However, what is also necessary is to find useful economic policy that would offer support to those who see their chance in performing some activities that are based on the usage of resources from special nature reserves. Well-informed population is one of the secure ways towards qualitative protection and sustainable development, both of protected natural resources and their hinterland.

One of the ways to protect and populate these areas can be the development of sustainable tourism and ecotourism. Interests for the reserves have already been shown both on domestic and international market. This contemporary social phenomenon is desirable in protected natural resources and as such it can considerably complete sustainable exploitation of wet- lands. The incomes from sold tickets, boat renting, professional guiding services, sold tickets for local ethno-museums and other tourist-catering services can be used to finance nature protection. It is true that those incomes would rather not be high, but under conditions of steady economic and social situations, and in combination with other economic activities, they should gain importance. Apart from the economic component, tourism could have much wider importance for special nature reserves. This activity can have an important role in the popularization of problems in the protection of wetlands.

Finally, it should not be forgotten that the principle of "deep ecology" would insist that the only right procedure is the one that gravitates towards the preservation of integrity, stability and the beauty of nature and ecosystems. It is wrong to gravitate towards something else. It is our duty to give up our wrong habits in order to enable natural unities of wetlands to develop undisturbingly.

\section{References}

Bukurov, B. 1975. Fizičko - geografski problemi Bačke. Srpska akademija nauka i umetnosti. Odeljenje prirodno-matematičkih nauka, knjiga 43, Beograd, pp. 1-250.

Dedić, M., Božić, Đ. 1998. Režim voda područja omeđenog Dunavom i Mostongom, Mostonga i vode Zapadne Bačke. Edicija Tija voda, Kulturno-istorijsko društvo "Proleće na čenejskim salašima”, Novi Sad pp. 23-32.

Dudas, G. 1896. A honfoglalastol a mohacsi veszig. Bacs - Bodrogh varmegye egyetemes monografiaja I, Zombor.

Milošev, Ž. 1998. Slivno područje i formiranje vodotoka Mostonge. Edicija Tija voda, Kulturno - istorijsko društvo "Proleće na čenejskim salašima", Novi Sad, pp. 17-21.

Puzović, S., 2002. Plantaže topola i zaštita vlažnih staništa i biodiverziteta. Šume, broj 67, Srbijašume, Beograd.

Primack, R. 1993. Essentials of Conservation Biology. Sinauer Associates Inc. Sunderland, Massachusetts.

Radovanović, S. 1997. Vojvođanski spomenar. NIC Plavi Zmaj, Sremski Karlovci, Tiski cvet, Novi Sad.

Stojanović, V. 2004. Primena koncepta održivog razvoja u specijalnim rezervatima prirode Vojvodine. Doktorska disertacija u rukopisu. Departman za geografiju, turizam i hotelijerstvo, PMF, Novi Sad, pp. 1-17o.

The Convention on Wetlands - brochure, 2000.

Zakon o zaštiti životne sredine, "Službeni glasnik Republike Srbije", broj 66, 1991.

Wetland, values and functions, Ramsar Convention Bureau. 